\title{
Bahaya Pembalut Wanita Melalui Personal Hygiene Remaja Putri Saat Mentruasi di Desa Demakan, Jaten, Karanganyar
}

\author{
Danger of The Sanitary Napkins through The Personal Hygiene Teenage when The Mind \\ Mentruation in The Village, Jaten, Karanganyar \\ Liss Dyah Dewi Arini* dan Udi Budi Harsiwi \\ APIKES Citra Medika Surakarta \\ *Corresponding author: leeansz_fortune@yahoo.com, sweetytiwi88@gmail.com
}

\begin{abstract}
ABSTRAK
Pada remaja perempuan menstruasi adalah hal yang lazim terjadi setiap bulan. Pembalut merupakan sahabat dekat perempuan. Pembalut yang banyak beredar di pasaran belum sepenuhnya dapat memberi jaminan kesehatan bagi kaum perempuan. Selain itu personal hygiene pada saat menstruasi dari setiap remaja putri pun berbeda-beda dan belum sepenuhnya sesuai dengan kesehatan. Tujuan penelitian adalah mengetahui tingkat pengetahuan mengenai personal hygiene remaja putri selama menstruasi menurut kesehatan pada remaja putri di desa Demakan Ngringo, Jaten, Karanganyar. Metode yang digunakan adalah penelitian non eksperimen dengan menggunakan analisis deskriptif dan dengan cara member kuesioner. Hasil dari penelitian ini adalah dari 30 sampel remaja putri yang telah mengisi kuesinoner untuk pertanyaan sikap dan tindakan diperoleh data sebagai berikut : Satu, untuk pertanyaan sikap, delapan belas (60\%) remaja putri sudah mempunyai sikap baik pada personal hygiene pada saat menstruasi, sedangkan tujuh (23\%) orang pada kriteria yang cukup dan sisanya lima (17\%) orang masih kurang; Dua, untuk pertanyaan tindakan, delapan belas (60\%) remaja putri sudah mempunyai sikap baik pada personal hygiene pada saat menstruasi, sedangkan tujuh (23\%) orang pada kriteria yang cukup dan sisanya lima (17\%) orang masih kurang.
\end{abstract}

Kata kunci : Pembalut, personal hygiene, remaja putri

\section{ABSTRACT}

In adolescent women menstruation is a common thing every month. Sanitary napkin is a close friend of women. Sanitary napkins are widely circulated in the market has not been fully able to provide health insurance for women. In addition, personal hygiene at the time of menstruation of each adolescent daughter is different and not fully fit with health. The purpose of this study was to know the level of knowledge about the personal hygiene of adolescent girls during menstruation according to the health of young women in Demakan Ngringo village, Jaten, Karanganyar. The method used is non experimental research using descriptive analysis and by way of questionnaire. The result of this research is from 30 samples of teenage girls who have filled out questionnaires for attitude and action questions obtained data as follows: One, for attitude question, eighteen (60\%) adolescent girls already have good attitude on personal hygiene at menstruation, while seven (23\%) people on the criteria sufficient and the remaining five (17\%) people are still lacking; Two, for action questions, eighteen (60\%) adolescent girls already had a good attitude on personal hygiene at the time of menstruation, while seven (23\%) people on the criteria sufficient and the remaining five (17\%) people are still lacking.

Keywords: Sanitary napkins, reproductive health, young women

\section{PENDAHULUAN}

Remaja adalah seseorang yang dari masa anak dengan bertambahnya usia akan berubah pada pola pikirnya menjadi lebih baik dan dapat menentukan yang baik dan buruk. Pada remaja putri menstruasi adalah hal yang lazim terjadi setiap bulan. Saat-saat menstruasi dapat menimbulkan banyak perubahan perilaku, suasana hati dan gairah. Hal ini terbilang wajar karena satu hal yang sering luput dari perhatian perempuan adalah bagaimana tetap menjaga kebersihan organ intim pada saat menstruasi. Pengetahuan dalam memilih pembalut saat menstruasi akan sangat penting untuk menghindari penyakit berbahaya. Hali ini disebabkan karena remaja putri yang masih awam atau baru mengenal menstruasi pertama kali belum begiu mengerti cara memilih pembalut yang sehat, karena kebanyakan dari mereka akan memilih jenis pembalut dengan tipe yang menarik dari segi bentuk, 
warna, merk tanpa mempertimbangkan kenyamanan dan kesehatan dari pembalut yang digunakan.

Pembalut yang banyak beredar di pasaran belum sepenuhnya dapat memberi jaminan kesehatan bagi kaum perempuan. Banyaknya merk pembalut perempuan, seringkali membingungkan, karena apakah semua pembalut perempuan aman digunakan. Menurut WHO, Indonesia merupakan negara dengan penderita kanker mulut rahim nomor 1 di dunia, dan $62 \%$ salah satunya diakibatkan oleh penggunaan produk pembalut yang tidak berkualitas. Di Rumah Sakit Citra Medika 400 pasien kanker leher rahim baru setiap tahunnya dan hal tersebut baru dari satu rumah sakit dan kematian akibat kanker servikks sekitar 66\% (Tjasmini, 2014).

Penggunaan pembalut pada organ intim perempuan menyebaban organ intim dalam keadaan lingkungan yang panas, lembab dan tanpa oksigen dalam waktu yang lama selama menstruasi berlangsung. Hal ini menimbulkan ketidaknyamanan dan mudah menimbulkan keberadaan bakteri penyebab berbagai macam penyakit ginekologis (Imron, 2011).

Penelitian ini bertujuan untuk mengetahui tingkat pengetahuan remaja putri khususnya di desa Demakan, Jaten, Karanganyar mengenai personal hygiene remaja putri selama menstruasi menurut kesehatan.

\section{METODE PENELITIAN}

Cara penelitian yang digunakan dalam penelitian ini adalah non eksperimen. Penelitian survei adalah penelitian yang dilakukan tanpa melakukan intervensi terhadap subjek penelitian (masyarakat) sehingga sering disebut penelitian non eksperimen (Notoatmodjo, 2012). Penulis hanya memberikan kuesioner (Tabel 1 dan 2) yang harus diisi dengan tanda check list $(\sqrt{ })$ oleh para remaja dan selanjutnya mengolah jawaban yang didapat dari kuesioner. Sampel pada penelitian ini adalah berjumlah tiga puluh remaja putri di desa Demakan, Jaten, Karanganyar. Cara mengolah data dari hasil kuesioner ini adalah dengan memberi skoring menggunakan pendekatan skala Likert.

Analisis penelitian yang digunakan adalah analisis deskriptif yaitu penelitian yang dilakukan untuk mendeskripsikan atau menggambarkan fenomena yang terjadi di masyarakat (Notoatmodjo, 2012).

\section{HASIL PENELITIAN}

\section{Hasil Pengisian Kuesioner pada Remaja Putri di desa Demakan, Ngringo, Ka- ranganyar, Jawa Tengah (Tabel 3)}

Hasil penelitian menunjukkan bahwa dari 30 sampel remaja putri yang telah mengisi kuesinoner untuk pertanyaan sikap dan tindakan diperoleh data sebagai berikut: Satu, untuk pertanyaan sikap, delapan belas $(60 \%)$ remaja putri sudah mempunyai sikap baik pada personal hygiene pada saat menstruasi, sedangkan tujuh (23\%) orang pada kriteria yang cukup dan sisanya lima (17\%) orang masih kurang; Dua, untuk pertanyaan tindakan, delapan belas (60\%) remaja putri sudah mempunyai sikap baik pada personal hygiene pada saat menstruasi, sedangkan tujuh (23\%) orang pada kriteria yang cukup dan sisanya lima (17\%) orang masih kurang.

\section{PEMBAHASAN}

Pembalut merupakan sahabat dekat perempuan. Karena menurut riset, seorang perempuan akan membutuhkan pembalut kira-kira selama 30-40 tahun dalam masa hidupnya. Dalam masa tersebut, seorang perempuan dapat menghabiskan sekitar 15.000 lembar pembalut. Begitu besar dan lamanya masa membutuhkan pembalut, maka perempuan disarankan memilih pembalut yang berkualitas baik. Tujuannya adalah agar kesehatan organ intim selalu terpelihara dan perempuan dapat menjalani hari-hari menstruasi dengan rasa nyaman dan senang (Halima dan Rahman, 2014). 
Tabel 1. Pertanyaan Sikap

\begin{tabular}{|c|c|c|c|c|}
\hline No & Pertanyaan & SS & $\mathrm{S}$ & $\mathrm{TS}$ \\
\hline 1 & $\begin{array}{l}\text { Penanganan selama haid tidak } \\
\text { steril dapat mengakibatkan } \\
\text { infeksi alat reproduksi }\end{array}$ & & & \\
\hline 2 & $\begin{array}{l}\text { Kebersihan daerah kemaluan } \\
\text { harus diperhatikan setiap saat }\end{array}$ & & & \\
\hline 3 & $\begin{array}{l}\text { Selalu menggunakan tissue } \\
\text { toilet merupakan cara dalam } \\
\text { membersihkan daerah } \\
\text { kewanitaan }\end{array}$ & & & \\
\hline 4 & $\begin{array}{l}\text { Saat haid menggunakan } \\
\text { pembalut dengan bahan yang } \\
\text { mengandung parfum dan bisa } \\
\text { dipakai seharian }\end{array}$ & & & \\
\hline 5 & $\begin{array}{l}\text { Lebih baik menggunakan kain } \\
\text { sebagai pembalut } d \text { aripada } \\
\text { menggunakan pembalut yang } \\
\text { bermerk }\end{array}$ & & & \\
\hline 6 & $\begin{array}{l}\text { Cara membasuh alat kelamin } \\
\text { adalah arah belakang ke depan }\end{array}$ & & & \\
\hline 7 & $\begin{array}{l}\text { Membersihkan alat kelamin } \\
\text { harus menggunakan sabun } \\
\text { mandi }\end{array}$ & & & \\
\hline 8 & $\begin{array}{l}\text { Cara membersihkan pembalut } \\
\text { yang benar adalah mencucinya } \\
\text { sampai tidak tersisa lagi s isa } \\
\text { darah kemudian dibuang ke } \\
\text { tempat sampah }\end{array}$ & & & \\
\hline 9 & $\begin{array}{l}\text { Bahan celana dalam lebih baik } \\
\text { terbuat dari nilon karena nilon } \\
\text { menghisap air dan tidak } \\
\text { tembus udara yang diperlukan } \\
\text { untuk aliran udara bebas ke } \\
\text { bagian luar alat kelamin }\end{array}$ & & & \\
\hline
\end{tabular}

Keterangan: SS: Sangat Setuju, S: Setuju, TS: Tidak Setuju Tabel 2. Pertanyaan Tindakan

\begin{tabular}{|c|c|c|c|}
\hline No & Pertanyaan & Ya & Tidak \\
\hline 1 & $\begin{array}{l}\text { Apakah anda sebelum dan } \\
\text { sesudah membersihakan daerah } \\
\text { kewanitaan dengan membasuh } \\
\text { tangan dengan sabun }\end{array}$ & & \\
\hline 2 & $\begin{array}{l}\text { Apakah anda membasuh daerah } \\
\text { kewanitaan menggunakan air } \\
\text { bersih }\end{array}$ & & \\
\hline 3 & $\begin{array}{l}\text { Apakah anda membasuh } \\
\text { kewanitaan dari arah depan ke } \\
\text { belakang setelah buang air } \\
\text { kecil/buang air besar }\end{array}$ & & \\
\hline 4 & $\begin{array}{l}\text { Apakah anda menggunakan tissue } \\
\text { toilet setelah membersihkan } \\
\text { kewanitaan }\end{array}$ & & \\
\hline 5 & $\begin{array}{l}\text { Apakah anda sering mengganti } \\
\text { pembalut saat menstruasi }\end{array}$ & & \\
\hline 6 & $\begin{array}{l}\text { Apakah anda mengganti pembalut } \\
\text { lebih dari } 2 \mathrm{x} \text { sehari }\end{array}$ & & \\
\hline 7 & $\begin{array}{l}\text { Apakah anda ering memakai } \\
\text { pewangi vagina (deodoran) }\end{array}$ & & \\
\hline 8 & $\begin{array}{l}\text { Apakah anda menggunakan } \\
\text { celana yang tidak mudah } \\
\text { menyerap keringat }\end{array}$ & & \\
\hline 9 & $\begin{array}{l}\text { Apakah anda langsung } \\
\text { mengantikan pembalut setelah } \\
\text { dareah haid sudah banyak }\end{array}$ & & \\
\hline 10 & $\begin{array}{l}\text { Apakah anda selal u membawa } \\
\text { pengganti pembalut saat } \\
\text { bepergian }\end{array}$ & & \\
\hline
\end{tabular}


Tabel 3. Hasil Pengisian Kuesioner pada Remaja Putri di desa Demakan, Ngringo, Karanganyar, Jawa Tengah

\begin{tabular}{|c|c|c|c|c|c|c|c|}
\hline \multirow{3}{*}{ No } & \multirow{3}{*}{$\begin{array}{l}\text { Res } \\
\text { pon } \\
\text { den }\end{array}$} & \multicolumn{6}{|c|}{ Kriteria } \\
\hline & & \multicolumn{3}{|c|}{ Sikap } & \multicolumn{3}{|c|}{ Tindakan } \\
\hline & & B & $C$ & $\mathrm{~K}$ & $\mathrm{~S}$ & $C$ & $\mathrm{~K}$ \\
\hline 1 & 1 & $\mathrm{k}$ & $u k$ & & $\sqrt{ }$ & $u k$ & \\
\hline 2 & 2 & & & $\sqrt{ }$ & & & $\sqrt{ }$ \\
\hline 3 & 3 & $\sqrt{ }$ & & & $\sqrt{ }$ & & \\
\hline 4 & 4 & $\sqrt{ }$ & & & $\sqrt{ }$ & & \\
\hline 5 & 5 & & & $\sqrt{ }$ & & & $\sqrt{ }$ \\
\hline 6 & 6 & $\sqrt{ }$ & & & $\sqrt{ }$ & & \\
\hline 7 & 7 & $\sqrt{ }$ & & & $\sqrt{ }$ & & \\
\hline 8 & 8 & $\sqrt{ }$ & & & $\sqrt{ }$ & & \\
\hline 9 & 9 & $\sqrt{ }$ & & & $\sqrt{ }$ & & \\
\hline 10 & 10 & $\sqrt{ }$ & & & $\sqrt{ }$ & & \\
\hline 11 & 11 & $\sqrt{ }$ & & & $\sqrt{ }$ & & \\
\hline 12 & 12 & $\sqrt{ }$ & & & $\sqrt{ }$ & & \\
\hline 13 & 13 & $\sqrt{ }$ & & & $\sqrt{ }$ & & \\
\hline 14 & 14 & & & $\sqrt{ }$ & & & $\sqrt{ }$ \\
\hline 15 & 15 & $\sqrt{ }$ & & & $\sqrt{ }$ & & \\
\hline 16 & 16 & $\sqrt{ }$ & & & $\sqrt{ }$ & & \\
\hline 17 & 17 & & & $\sqrt{ }$ & & & $\sqrt{ }$ \\
\hline 18 & 18 & & $\sqrt{ }$ & & & $\sqrt{ }$ & \\
\hline 19 & 19 & & $\sqrt{ }$ & & & $\sqrt{ }$ & \\
\hline 20 & 21 & & $\sqrt{ }$ & & & $\sqrt{ }$ & \\
\hline 21 & 21 & $\sqrt{ }$ & & & $\sqrt{ }$ & & \\
\hline 22 & 22 & $\sqrt{ }$ & & & $\sqrt{ }$ & & \\
\hline 23 & 23 & $\sqrt{ }$ & & & $\sqrt{ }$ & & \\
\hline 24 & 24 & & & $\sqrt{ }$ & & & $\sqrt{ }$ \\
\hline 25 & 25 & & $\sqrt{ }$ & & & $\sqrt{ }$ & \\
\hline 26 & 26 & & $\sqrt{ }$ & & & $\sqrt{ }$ & \\
\hline 27 & 27 & $\sqrt{ }$ & & & $\sqrt{ }$ & & \\
\hline 28 & 28 & $\sqrt{ }$ & & & $\sqrt{ }$ & & \\
\hline 29 & 29 & & $\sqrt{ }$ & & & $\sqrt{ }$ & \\
\hline 30 & 30 & & $\sqrt{ }$ & & & $\sqrt{ }$ & \\
\hline
\end{tabular}

Keterangan: B: Baik, K: Kurang, C: Cukup, S: Sesuai

Pembalut merupakan adalah sebuah perangkat yang digunakan oleh perempuan di saat menstruasi. Pembalut berfungsi untuk menyerap darah dari vagina supaya tidak kemanamana. Selain saat menstruasi, perangkat ini juga digunakan setelah pembedahan vagina, setelah melahirkan, maupun situasi lainnya yang membutuhkan pembalut untuk menyerap setiap cairan yang berupa pendarahan pada vagina (Winerungan, 2013).

Pembalut perempuan adalah sebuah perangkat yag diguakan oleh perempuan di saat menstruasi dan berfungsi untuk menyerap darah dari vagina supaya tidak kemana-mana. Berdasarkan hasil jawaban kuesioner dari para responden dapat disimpulkan pengertian pembalut menurut responden adalah bahan atau alat yang diperlukan wanita untuk menyerap darah saat menstruasi, tetapi ada satu responden yang tidak bisa mendefinisikan pembalut dika- renakan responden tersebut masih bingung untuk menjawab, sehingga secara keseluruhan para espoden sudahmengetahui apa itu pembalut (Gustin, 2016).

Ciri-ciri pembalut yang baik adalah bersih dan tidak mengandung zat asing, tidak menimbulkan iritasi atau alergi, tidak berbau, netral dan juga lembut. Daya serap pembalut yang ideal adalah 10x lipat dari berat pembalut. Untuk responden yang lain mereka menjawab elegan, tipis, tidak mengganjal, bagus, ikutikyran dan yang sesuai dengan yang dipakai, kurangnya penegrtahuan para remaja belum mengetahi cara memilih pembalut yang baik.

Menurut penelitian terdapat 107 bakteri per milimeter persegi ditemukan di atas pembalut wanita biasa. Secara teori pembalut harus diganti setiap 2-3 jam sekali atau sesuai dengan volume darah yang keluar. Semua reponden mengganti pembalutnya dalam satu hari sebanyak 2-3 
kali, jika pembalut dipakai lebih dari 2 jam maka penyebaran bakteri di pembalut ke rahim akan lebih banyak dan resiko terkena kanker leher rahim akan semakin besar (Arsani, 2013).

Pembalut yang tidak baik menimbulkan berbagai penyakit antara lain adalah kanker rahim, myom, kista, kecacatan pada bayi dan infeksi. Dari sepuluh responden yang diminta informasinya delapan responden sudah mengetahui tentang pembalut dengan baik sedangkan satu responden masih kurang dalam pengetahuan tentang pembalut, delapan responden memilih pembalut yang lembut, nyaman, tidak mudah berkerut dan tidak mudah geser serta pembalut yang mudah dicuci.

Kurangnya wawasan kaum hawa soal pembalut memang sangat memprihatinkan. Kebanyakan dari mereka asal-asalan membeli pembalut tanpa tau jenis dan macamnya, lebih-lebih para remaja yang justru menyepelekan kualitas pembalut yang mereka beli. Hampir semua perempuan tidak pernah tahu tentang pembalut yang biasa mereka beli dan pakai selama ini. Dan mereka tidak pernah curiga dan tidak pernah mencoba merobek atau mengamati bahan pembalut biasa yang ada di pasaran hanya memikirkan harga murah dan cukup enak dipakai, tanpa mengetahui sedikit[un resiko kesehatan dari pemakaian pembalut atau penyakit pantyliner biasa (BKKBN, 2012).

Wanita justru suka memilih pembalut yang menarik baik bentuk ataupun warnanya, apalagi jika beli dua bungkus gratis satu, mereka pasti tidak akan menolaknya memilih kriteria pembalut yang mengacu pada kualitas kesehatan dan keamananya haruslah dijadikan pedoman kaum wanita agar terhindar dari bahaya pemakaian pembalut.

Produk pembalut wanita haruslah bersih dan tidak mengandung zat berbahaya, ini karena pembalut kontak langsung dengan area intim wanita yang seharusnya terjaga baik kebersihan maupun kesehatannya. Di antara ciri-ciri pembalut yang baik adalah bersih dan tidak mengan- dung zat asing. Tidak menimbulkan iritasi atau alergi, tidak berbau, netral dan juga lembut.

Daya serap sebuah pembalut yang ideal adalah sepuluh kali lipat dari berat pembalut, jika itu tidak terpenuhi maka bisa dipastikan pembalut tersebut tidak memenuhi standar. Sementara soal warna, pembalut haruslah putih dan tidak mengandung zat pewarna. Selain hal di atas, pembalut seharusnya juga diberi tanggal kadaluarsa (Fitriyah, dkk, 2013). Masalahnya adalah hampir semua kriteria pembalut yang ideal ini tidak terpenuhi di Indonesia, meskipun kita sama-sama tau banyak sekali merk pembalut di pasaran. Selain ciri-ciri di ats tips yang dapat dilakukan untuk mengetes pembalut yang aman menurut Purwatingsih dan Furi (2010) antara lain adalah:

a. Pilihlah pembalut yang cocok (tidak menimbulkan gatal-gatal atau bahkan iritasi saat digunakan).

b. Pilihlah pembalut yang lembut dengan daya serap tinggi

c. Hindarilah pembalut yang lembut dengan daya serap tinggi

d. Gunakan pembalut hanya satu kali pakai jangan mencuci lalu menggunakannya,

e. Ganti pembalut tiap 2-3 jam sekalu

f. Jangan utamakan yang murah, tapi utamakanlah yang berkualitas

g. Jika terjadi iritasi atau gatal-gatal pada area mis $\mathrm{V}$ setelah memakai pembalut, maka cobalah merk pembalut yang lain.

Waspada dengan pembalut wanita berbahaya yang beredar di pasaran. Pembalut adalah suatu kebutuhan dasar seorang wanita terutama ketika ia mengalami haid. Tidak ada kriteria khusus saat memilih pembalut sebab yang terpenting adalah kemampuan pembalut dalam menyerap darah. Saat memakai pembalut, pastikan bahwa tidak mengalami alergi sebab ada beberapa pembalut yang telah diberi pewarna dan pemutih buatan yang tidak baik untuk kesehatan organ reproduksi. Beberapa tes untuk mengukur tingkat keamanan pembalut yang digu- 
nakan menurut Tanjung, dkk (2001) adalah :

a. Tes daya serap pembalut

i. Masukkan air sekitar $35-50 \mathrm{ml} / \mathrm{cc}$ pada permukaan pembalut

ii. Diamkan beberapa saat lalu tekan selembar tisu ke permukaan pembalut (usahakan tekan agak kuat seperti jika pembalut yang dipakai kita duduki).

iii. Jika tisu basah itu tandanya berarti daya serap pembalur kurang memadai dan sebaiknya jangan menggunakan pembalut jenis tersebut. Karena jika permukaan pembalut basah karena daya serap yang minim, makan kelembabab miss $\mathrm{V}$ akan terganggu, jika terjadi terus-menerus maka akan semakin banyak bakteri yang tumbuh di area intim kita.

b. Tes kualitas dan kandungan berbahaya pembalut

i. Siapkan setengah gelas air putih, usahakan gunakan gelas kaca yang bening agar proses tes bisa terlihat. Siapkan juga batang pengaduk, bisa menggunakan sumpit atau batang sendok.

ii. Sobek pembalut dan ambil bagian dalam pembalut yang berupa kapas atau bahan penyerap. Masukkan kapas atau bahan penyerap yang sudah diambil sebagian saja ke dalam gelas yang berisi air.

iii. Apakah kapas atau bahan penyerap hancur seperti kertas atau hanya airnya saja yang keruh. Jika hancur seperti kertas berarti bahan pembalut tersebut kurang berkualitas dan jika airnya keruh maka bahan pembalut tersebut mengandung bahan berbahaya seperti pewarna klorin.

Menurut Badan Kesehatan Dunia (WHO), Indonesia merupakan negara dengan penderita kanker mulut rahim nomor satu di dunia dan $62 \%$ diakibatkan oleh penggunaan pembalut yang kurang berkualitas. DI RSCM, 400 pasien kanker serviks baru setiap tahunnya. Di RSCM, kematian akibat kanker serviks sekitar 66\%. Menurut penelitian terdapat 107 bakteri per milimeter persegi ditemukan di atas pembalut wanita biasa, kondisi inilah yang membuat pembalut biasa menjadi sumber sarang pertumbuhan bakteri merugikan, merk pembalut biasa hanya dipakai selama 2 jam saja $(\mathrm{BKKBN}$, 2012).

Masalah haid akibat pembalut berkualitas buruk saat sedang haid dan memakai pembalut biasa tanpa disadari cairan yang sudah diserap oleh pembalut biasa yang sudah bercampur dengan kimia dan bercampur dengan bahan yang tidak steril dari pembalut biasa. Dan saat seorang wanita duduk tanpa disadari maka cairan kotor dari pembalut akan akan keluar kembali karena terkena tekanan dan naik ke atas dan masuk kembali ke organ kewanitaan. Hal ini yang akan menyebabkan infeksi dan timbulnya masalah kewanitaan. Tanda-tanda terjadinya infeksi bagi wanita haid antara lain adalah haid, sering buang air kecil, pusing, sakit perut/ mual, keputihan, sakit pinggang, sakit ketika buang air kecil dan pembalut yang kurang baik dapat menyebabkan kanker rahim, myom, kerusakan hormon. Kista san meningkatkan resiko cacat pada bayi (Wulandari, dkk, 2012).

Betapa repotnya bagi seorang wanita yang sedang mengalami menstruasi dan harus tetap menjalankan aktifitas. Mungkin perlu beberapa kali dalam sehari mengganti di rumah, di tempat kerja dan bahkan di perjalanan. Pembalut yang sudah terpakai jika tidak dikelola dengan baik dapat menimbulkan beberapa permasalahan. Masalah yang pertama adalah masalah lingkungan, masalah kesehatan dan tentunya masalah estetika. Berbeda dengan sampah pada umumnya, pembalut yang sudah terpakai selain berpotensi menumpuk sebagai sampah, karena mengandung darah dari jaringan tubuh (Soetjiningsih, 2007).

Pembalut yang sudah terpakai pasti berisi darah dan bahan-bahan organik dari tubuh yang berasal dari peluruhan endometrium. Dari sisi kesehatan tentu hal ini memerlukan perhatian dalam penanganannya. Bahan organik tersebut 
dapat mengalami pembusukan dan memunculkan bau yang tidak sedap. Warna darah yang membekas pada pembalut secara estetika juga terlihat tidak nyaman untuk dilihat kalau pembalut bekas dibuang di tempat sembarangan (Maryanti, 2009).

Menurut Rahman (2014) ada beberapa tips yang bisa dilakukan untuk mengelola pembalut yang sudah dipakai dengan memperhatikan halhal di atas, yaitu:

a. Biasanya cairan menstruasi yang keluar terserap oleh bahan pembalut karena terbuat dari bahan yang mudah menyerap cairan. Kalau darah yang keluar banyak, seringkali bekasnya berwarna merah darah dengan sangat terlihat dan terkadang terdapat gumpalan darah. Dalam situasi seperti ini seringkali seseorang merasa perlu untuk mencucinya terlebih dahulu dengan tujuan agar bekas tersebut tidak terlalu terlihat. Yang perlu diperhatikan adalah air bekas cucian jangan sampai mengalir ke tempat terbuka dan mengganggu estetika. Kloset dengan kelengkapan septic tank adalah tempat yang cukup baik untuk sebagai tempat membuang air bekas cucian.

b. Gulunglah pembalut dengan noda darah ada di dalam kemudian bungkus pembalut yang sudah terpakai dengan kertas atau bahan lain kemudian buang ke tempat sampah. Dengan demikian, kebersihan dan estetika sudah bisa dijaga.

Pembalut yang sudah terpakai jika tidak dikelola dengan baik dapat menimbulkan beberapa permasalahan. Bahan organik tersebut dapat mengalami pembusukan dan memunculkan bau yang tidak sedap. Warna darah yang membekas pada pembalut secara estetika juga terlihat tidak nyaman untuk dilihat kalau pembalut bekas dibuang di tempat sembarangan. Pembalut yang sudah terpakai sebaiknya dicuci terlebih dahulu agar darah di pembalut hilang lalu pembalut digulung dan selanjutnya dibakar jangan dibuang di sungai karena akan menye- babkan banjir. Lima responden menjawab langsung dibuang di sungai karena akan menyebabkan banjir. Lima responden menjawab langsung dibuang ada yang di sungai dan ada yang dibakar tanpa dicuci terlebih dahulu, itu akan menimbulkan banjir jika dibuang di sungai dan mengganggu pemandangan orang lain serta menimbulkan bau karena pembalut yang terdapat darah tidak dicuci sebelum dibuang, sedangkan responden yang lainnya sebelum dibuang dicuci terlebih dahulu (Isomawati, 2011).

Personal gygiene pada saat menstruasi dapat dilihat dari kriteria sikap sebagai berikut: penanganan selama haid harus steril sehingga terbebas dari infeksi alat reproduksi, kebersihan daerah kemaluan harus diperhatikan setiap saat, selalu menggunakan tissue toilet dalam membersihkan daerah kewanitaan, saat haid menggunakan pembalut dengan bahan yang tidak beraroma, cara membasuh alat kelamin adalah arah depan ke belakang, membersihkan alat kelamin harus menggunakan sabun mandi jangan sabun kewanitaan karen akan merusak pH organ intim, cara membersihkan pembalut yang benar adalah mencucinya sampai tidak tersisa lagi sisa darah kemudian dibuang ke tempat sampah dan bahan celana dalam lebih baik terbuat dari nilon karena nilon menghisap air dan tidak tembus udara yang diperlukan untuk aliran udara bebas ke bagian luar alat kelamin (A, 2017).

Personal gygiene pada saat menstruasi dapat dilihat dari kriteria tindakan sebagai berikut: sebelum dan sesudah membersihakan daerah kewanitaan dengan membasuh tangan dengan sabun, membasuh daerah kewanitaan menggunakan air bersih, membasuh kewanitaan dari arah depan ke belakang setelah buang air kecil/buang air besar, menggunakan tissue toilet setelah membersihkan kewanitaan, sering mengganti pembalut saat menstruasi sebanyak 3-5 kali, tidak memakai pewangi vagina (deodoran), menggunakan celana yang mudah me- 
nyerap keringat, langsung mengantikan pembalut setelah daerah haid sudah banyak dan selalu membawa pengganti pembalut saat bepergian (Cahyono dan Noerainin, 2016).

\section{KESIMPULAN DAN SARAN}

Hasil penelitian menunjukkan bahwa dari 30 sampel remaja putri yang telah mengisi kuesinoner untuk pertanyaan sikap dan tindakan diperoleh data sebagai berikut:

1) Satu, untuk pertanyaan sikap, delapan belas $(60 \%)$ remaja putri sudah mempunyai sikap baik pada personal hygiene pada saat menstruasi, sedangkan tujuh (23\%) orang pada kriteria yang cukup dan sisanya lima (17\%) orang masih kurang dalam pengetahuan personal gygiene pada saat menstruasi.

2) Dua, untuk pertanyaan tindakan, delapan belas $(60 \%)$ remaja putri sudah mempunyai sikap baik pada personal hygiene pada saat menstruasi, sedangkan tujuh $(23 \%)$ orang pada kriteria yang cukup dan sisanya lima orang (17\%) masih kurang dalam pengetahuan personal hygiene pada saat menstruasi.

\section{DAFTAR PUSTAKA}

A, Noor Latifah. 2017. "Gambaran Perilaku Hygiene Menstruasi pada Siswi SMKN 8 Kota Bekasi”. Jurnal Kedokteran dan Kesehatan, Vol.13, No. 1.

Arsani, Ni Luh. 2013. Peranan Program PK.RR (Pelayanan Kesehatan Peduli Remaja) Terhadap Kesehatan Reproduksi Remaja Di Kecamatan Buleleng. Jumal Ilmu Sosial Dan Humaniora, Vol. 2, No 1.

BKKBN. 2012. Bimbingan Teknis Kesehatan Reproduksi Dan Seksualitas Yang Komprehensif. JAK/2013/PI/H/29. Jakarta: Direktorat Bina Ketahanan Remaja Nasional.

BKKBN. 2012. Pedoman Pengelolaan Pusat Informasi dan Konseling Remaja dan Mahasiswa. Jakarta: Direktorat Bina Ketahanan Remaja Nasional.

Cahyono, Aris Dwi dan Noerainin, Amelia. 2016. "Pengetahuan Remaja Putri Tentang Personal Hygiene Saat Mentruasi”. Jurnal AKP Vol. 61 No.2.
Fitriyah, Nurul; Indriani, Diah dan Sulistyorini, Yuly. 2013. Riwayat Kesehatan Reproduksi Remaja Santri Jurnal Biometrika dan Kependudukan, Vol. 2, No. 2 Desember 2013: 182-19.

Gustin, Suvia. 2016. "Pengaruh Penyuluhan Kesehatan Kanker Serviks Terhadap Sikap Pencegahan Kanker Serviks Pada Siswi Kelas Viii Smp Negeri 15 Kota Yogyakarta”. Naskah Publikasi. Yogyakarta: Universitas Aisyiyah.

Halima, S dan Rahman, A Riskiyani. 2014. "Persepsi Remaja Tentang Kesehatan Reproduksi Di Pondok Pesantren Manahilil Ulum Hidaiyah Kabalangang Kabupaten Pinrang”. Jurnal AKK, Vol.3 no.1, hh 41-47.

Imron Ali. 2011. Pendidikan Kesehatan Reproduksi Remaja. Jogjakarta: Ar-Ruzz Media.

Isomawati, MD, dkk. 2011. Efektifitas Media AVA Dan Leaflet Dalam Penyuluhan Tentang HIV/AIDS Terhadap Peningkatan Pengetahuan Temaja Di SMP Negeri 1 Sumpiyuh Kabupaten Banyumas Tahun 2011. Jurnal kebidanan Vol 2 No 5 Oktober 2013 ISSN 2089-7669.

Maryanti, D Septikasari. 2009. Buku Ajar Kesehatan Reproduksi Teori dan Praktikum. Yogyakarta : Mulia Medika. Negeri X di Surabaya". Jurnal Promkes, Vol. 1, No. 2 Desember 2013: 184-191.

Notoatmodjoo. 2012. Metodologi Penelitian. Jakarta: Rineka Cipta.

Purwatingsih, Sri dan Furi, S.N.Y. 2010. Permisivitas Remaja dan Peran Sosial dalam Perilaku Seksual di Indonesia dalam Keluarga Berencana dan Kesehatan Reproduksi, Yogyakarta: Pustaka Pelajar kerja sama Pusat Studi Kependudukan dan Kebijakan UGM.

Rahman, Nita. 2014. " Faktor-Faktor yang Berhubungan dengan Perilaku Personal hygiene pada Saat Menstruasi di SMP 5 Muhammadyah Yogyakarta Tahun 2014“. Naskah Publikasi. Yogyakarta: STIKES Aisyiyah.

Soetjiningsih. 2007. Tumbuh Kembang Remaja dan Permasalahannya, Jakarta: Sagung Seto.

Tanjung, A., Utamadi, G., Sahajana, J. \& Tafal, Z. 2001. Kebutuhan akan informasi dan pelayanan kesehatan reproduksi remaja. Laporan need assessment di Kupang, Palembang, Singkawang, Cirebon dan Tasikmalaya. Jakarta: BKKBN \& UNFPA.

Tjasmini. 2014. "Pembelajaran Bina Diri Dalam Membantu Pemahaman Kesehatan Reproduksi Pada Remaja Putri Tunagrahita. Edutech, Tahun 13, Vol.1, No.2. ISSN : 08521190.

Winerungan, Ester Maria. 2013. Hubungan Pengetahuan Kesehatan Reproduksi Dengan Kejadian Iritasi Vagina Saat Menstruasi Pada Remaja Di Smp Negeri 8 Manado. ejournal keperawatan (e-Kp) Volume 1. Nomor 1.

Wulandari, Vicky Febry; Nirwana, Herman Dan Hurfarhanah. 2012. "Pemahaman Siswa Mengenai Kesehatan Reproduksi Remaja Melalui Layanan Informasi”. KONSELOR Jurnal Ilmiah Konseling. Volume 1 Nomor 1 Januari 2012. Hal 1-9. 